Article

\title{
Influence of Linseed Oil Varnish Admixture on Glauconite Clay Mortar Properties
}

\author{
Przemysław Brzyski * ${ }^{-10}$ and Magdalena Grudzińska \\ Faculty of Civil Engineering and Architecture, Lublin University of Technology, 40 Nadbystrzycka Str., \\ 20-618 Lublin, Poland; m.grudzinska@pollub.pl \\ * Correspondence: p.brzyski@pollub.pl; Tel.: +48-538-4448
}

Received: 9 November 2020; Accepted: 30 November 2020; Published: 2 December 2020

\begin{abstract}
Raw clay is used nowadays in construction as a component of mortars and plasters and as a binder in composites based on straw or shives. It is a material with good sorption properties and vapor permeability, but it is susceptible to shrinkage, is not resistant to water, and also is characterized by low mechanical strength, which makes it impossible to be used, for example, in external plasters. Various additives and admixtures are used to improve selected properties of clay mortars. The article presents the research results and assessment of the effect of glauconite clay mortar modification with an admixture of linseed oil varnish on selected properties. Admixtures in the amounts of $1 \%, 2 \%$, and $3 \%$ in relation to clay weight were used. Flexural and compressive strength, water resistance, shrinkage, drying capacity, density, and porosity of mortar, were tested. The admixture of linseed oil varnish in the amounts used in the investigation had a positive effect on some of the tested properties; regardless of the quantity of the admixture, the modified mortars had better parameters concerning flexural strength, shrinkage reduction, and water resistance than the reference mortar, without admixture.
\end{abstract}

Keywords: clay mortar; glauconite; linseed oil varnish; mechanical properties; water resistance

\section{Introduction}

Clay is one of the oldest building materials, commonly used in hot and temperate climate regions. It was applied widely as mortar and plaster binder or as a component of bricks and earth walls from 7000 B.C. until the present [1]. Clay composites have many advantages, such as a good accumulation of heat (helping to reduce overheating in hot regions and lower the energy use for heating in colder regions) [1], the capability of regulating moisture content in rooms [2-4], the possibility of recycling, and low extraction and transportation costs $[1,5]$. It can be used for protection purposes in timber constructions, increasing the resistance to biodegradation of the latter [6].

The growing popularity of sustainable, ecological buildings has increased the interest in earth mortars based on natural, raw materials with low carbon footprints, such as clay and lime $[7,8]$. However, the main problems limiting the wide adoption of these products in building practices are:

1. Low mechanical strength [5,9-11];

2. Shrinkage during the drying up process $[5,12,13]$;

3. Poor resistance to water penetration [14-16];

4. Low durability connected with poor frost resistance $[9,16,17]$.

In order to enhance the properties of mortars, many studies considered the influence of various additives and admixtures on the characteristics of fresh mixtures or hardened materials. In historic, vernacular architecture, for example, there are references to the use of organic components improving 
the mechanical properties, workability, and waterproofing of natural mortars $[6,12,15]$. Some of them have been recently rediscovered and investigated [18], including, among others, sheep wool $[9,19]$, animal glue [20], casein [20-22], eggs [21], olive oil [20], linseed oil [22-25], sunflower oil [26,27], straw [14,28-30], and hemp [31,32].

Inorganic substances, such as metakaolin [33-36], volcanic ash [37,38] and brick dust [35], because of their pozzolanic activity, can be, as well, used to improve the mechanical strength of cement-based and natural mortars. They can also diminish the shrinkage of the paste and mortar [33,35] and improve durability by reducing the liquid water transport [39].

Also man-made, processed supplements are examined as modifiers, affecting the properties of traditional building elements. The exemplary products mentioned in the literature are fly ashes [40], silica and alumina nanoparticles (stabilizing the material by reducing the shrinkage and increasing its early strength) [5], and aerogels (intended to increase the thermal resistance of the plaster) [41].

As the additives used in the presented research are meant to improve the resistance to water of the mortar, the description of the water-repellents will be extended. Among many substances, fatty acids are commonly used for this purpose. Linseed oil positively affects the impermeability and enhances the freezing and thawing resistance, thanks to the reduction in the capillary water absorption $[17,23,42]$. It also prevents crack development during curing [17] and reduces shrinkage as an effect of fostering the pozzolanic reaction [24]. The application of olive oil as an additive described in [20] reduced the pore size and lowered the water absorption of the mortar. Similar effects were obtained using oils from sunflower, peanuts, and rapeseeds [27]. The addition of spent cooking oils in the lime mortars produced a significant hydrophobic effect, diminishing capillary water transport [26].

The adverse consequences of such modification may be slower development and lower value of mechanical strength, as described in [23,25]. In some cases, however, the addition of fatty acids to the lime mortars significantly increased their hydrophobicity without worsening mechanical strength $[20,26]$.

Some water-repellent admixtures (produced by the chemical industry and typically used in cement-based mortars), namely sodium oleate, calcium stearate, or zinc stearate, are also investigated in lime-based mortars [43-45]. These substances decreased the water absorption level of analyzed material, without being highly detrimental to mechanical strength.

The hygrothermal performance of natural plasters can be also improved thanks to the application of finishing layers based on cellulose, casein, or lime [46]. However, as clay plasters are often used as the finishing of the stud walls insulated with hemp-lime composite $[47,48]$, it is important not to limit excessively their vapor permeability.

As presented above, there are many publications concerning the additives and admixtures that improve the durability and impermeability of mortars. However, no similar research on clay mortars can be found and this paper intends to complement this research area. It presents the results of studies on the application of local clay as a mortar binder, modified by the linseed oil varnish admixture. The examined clay has a high glauconite content, giving it a greenish tinge, and the use of this specific type of binder in building mortars has not been investigated before. One of the leading applications of glauconite is as a filter component for heavy metals' removal. As glauconite is a clay mineral and the clay mixture used was rich in loam fraction and showed a high binding capacity, the resulting admixture may have potential use as a building material. Selected properties of the obtained material, i.e., flexural and compressive strength, water resistance, shrinkage, drying capacity, density, and porosity, were tested.

\section{Materials and Methods}

\subsection{Mortar Recipes}

Four clay mortar recipes with a variable amount of linseed oil varnish admixture were examined in the work. They were marked as CM-0, CM-1, CM-2, CM-3, where CM means "clay mortar" and the number stands for the percentage of linseed oil varnish in relation to the clay weight. All the mortars 
had a clay to sand weight ratio of 1:4, while the water to clay weight ratio was 0.8 (lower values of the water to binder ratio did not ensure proper workability of the mortar). The recipes used in the investigation are shown in Table 1.

Table 1. Recipes of mortars (weight ratios in relation to clay).

\begin{tabular}{ccccc}
\hline Symbol & Clay & Sand & Linseed Oil Varnish & Water \\
\hline CM-0 & 1 & 4 & 0 & 0.8 \\
CM-1 & 1 & 4 & 0.01 & 0.8 \\
CM-2 & 1 & 4 & 0.02 & 0.8 \\
CM-3 & 1 & 4 & 0.03 & 0.8 \\
\hline
\end{tabular}

As a binder, the clay containing glauconite was applied. The raw clay material came from the sand mine in Gawłówka, Poland. The clay extracted from the mine included the sand fraction $(0.05-2 \mathrm{~mm})$ in the amount of $60 \%$, the silt fraction $(0.002-0.05 \mathrm{~mm})$ in the amount of $3 \%$, and the loam fraction $(<0.002 \mathrm{~mm})$ in the amount of $31 \%$ [49]. The sand fraction was separated, leaving a mixture of dusty and clay fractions. Glauconite is a soft mineral and its hardness is similar to that of mica minerals or slightly lower, usually around 2 on the Mohs scale. The specific density of clay was $2.68 \mathrm{~g} / \mathrm{cm}^{3}$ and the bulk density of the soil skeleton was $1.98 \mathrm{~g} / \mathrm{cm}^{3}$. The chemical composition of the glauconite clay used is shown in Table 2, the microstructure image is shown in Figure 1 and the clay minerals habit is shown in Figure 2. Table 2 and Figures 1 and 2 come from the publication [49] and relate to the characteristics of the glauconite clay used in this study.

Table 2. Chemical composition of glauconite clay used in the investigation [49].

\begin{tabular}{cc}
\hline Component & (\%) \\
\hline $\mathrm{SiO}_{2}$ & 51.12 \\
$\mathrm{Fe}_{2} \mathrm{O}_{3}$ & 19.00 \\
$\mathrm{MgO}$ & 4.74 \\
$\mathrm{Al}_{2} \mathrm{O}_{3}$ & 6.09 \\
$\mathrm{CaO}$ & 2.16 \\
$\mathrm{Na}_{2} \mathrm{O}$ & 0.05 \\
$\mathrm{~K}_{2} \mathrm{O}$ & 8.59 \\
$\mathrm{P}_{2} \mathrm{O}_{5}$ & 1.27 \\
$\mathrm{TiO}_{2}$ & 0.06 \\
\hline
\end{tabular}

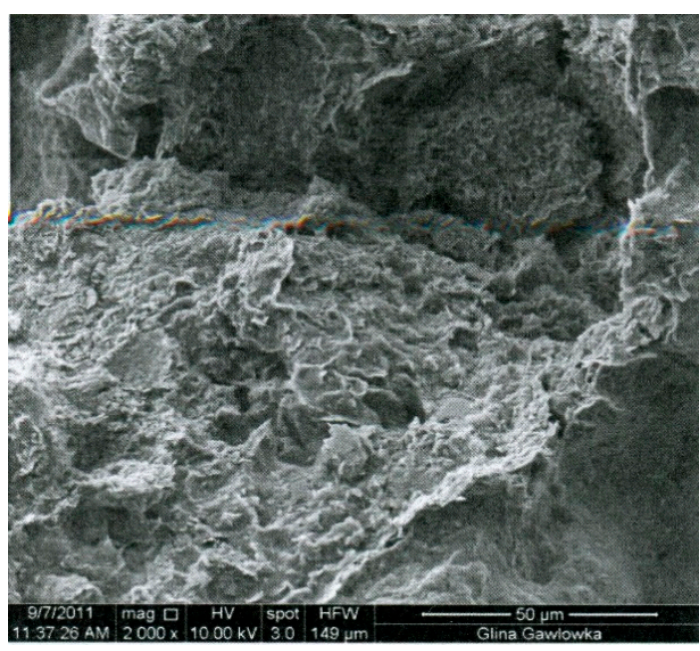

Figure 1. The microstructure of the examined clay [49]. 


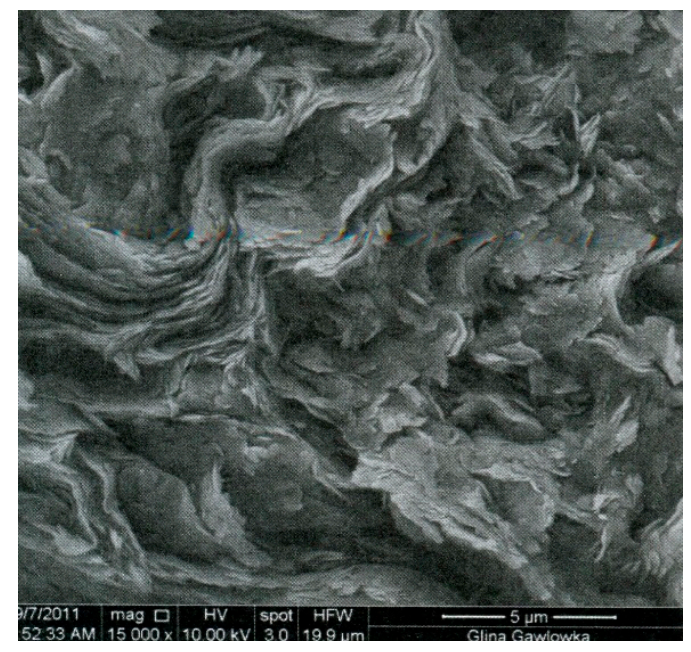

Figure 2. Clay minerals' habit in the tested clay [49].

Quartz sand with a fraction of 0-2 $\mathrm{mm}$ acted as a mortar filler. Linseed oil varnish in the form of a viscous liquid with a density of $900-940 \mathrm{~kg} / \mathrm{m}^{3}$ was used as an admixture, intended to improve the aforementioned properties of the examined material. Its viscosity, measured with a Ford cup $4 \mathrm{~mm}$ at $20{ }^{\circ} \mathrm{C}$, was $20-26 \mathrm{~s}$.

\subsection{Preparation of Mixture and Specimen}

Because of the different working properties of fresh clay mortar compared to lime or cement mortar, the procedure of mixture preparation was not based on existing standards. Before preparing the mortars, the hardened clay was dried, crushed into smaller pieces with a hammer, and then placed in pots with water. Part of the water (by mass ratio water:clay $=0.5$ ) was added to the weighed amount of clay according to the recipe, and then the mixture was weighed and soaked to allow the clay to soften for about $12 \mathrm{~h}$. After this time, the vessels with clay and water were reweighed. The remaining water was added, supplemented by the heated linseed oil varnish admixture. Heating of the varnish was conducted in order to liquefy it so that the substance could distribute more homogeneously in the mixture. Finally, the sand was added and the composite was mixed for 3 min with a mechanical agitator until a homogeneous material was obtained. The ready mortar was formed into moulds of $40 \mathrm{~mm} \times 40 \mathrm{~mm} \times 160 \mathrm{~mm}$ and stored in dry air conditions (temperature around $20^{\circ} \mathrm{C}$, relative humidity around $50 \%$ ). After 5 days of ripening, the samples were demoulded and left under the same conditions until air-dried.

\subsection{Research Methods}

\subsubsection{Apparent Density, Specific Density, and Total Porosity}

The apparent density test was carried out according to standard PN-EN 1015-6 [50] on three cubic specimens from each recipe. The specimens of known volume were dried and then weighed on a laboratory scale to calculate the apparent density. The specific density of mortars (the ratio of sample mass to volume excluding pores) was determined by the pycnometric method based on the PN-EN 1936: 2010 standard [51]. A sample of the composite to be tested was pulverized to the fraction below $0.063 \mathrm{~mm}$ by milling in a ball mill (Fritsch, Idar-Oberstein, Germany). Based on the specific and apparent density results, the total porosity was calculated as the percentage ratio of the open and closed pore volume to the total sample volume. 


\subsubsection{Resistance to Water}

To determine the destructive effect of water on the material, the resistance to water test was carried out on samples measuring $80 \mathrm{~mm} \times 40 \mathrm{~mm} \times 40 \mathrm{~mm}$. Before the test, the samples were dried to constant weight in a laboratory drier at $80^{\circ} \mathrm{C}$. Twelve samples from each recipe ( 48 in total) were used for the experiment. For each time step, three samples from each recipe were tested. The course of the study was as follows:

1. Three samples for each recipe (formerly dried to constant weight) were placed in a bath of water, so that they were completely submerged, for $1 \mathrm{~min}$, then taken out and dried again to constant weight;

2. After this first immersion stage, significant losses were noticed in the CM-0 samples, so it was decided to reduce the duration of the following immersion periods for the samples without varnish; thus, in the next three stages they were dipped for the periods of $5 \mathrm{~s}, 15 \mathrm{~s}$, and $30 \mathrm{~s}$, according to the above procedure;

3. The duration of the immersion time for the samples with varnish instead, was maintained at 3,5, and $7 \mathrm{~min}$, since no extreme reduction was noticed in these samples;

4. The same procedure explained at point 1 was repeated for the duration mentioned at point 2 (for CM-0 samples) and point 3 (for CM-1, CM-2, and CM-3 samples).

The experiment made it possible to calculate the percentage weight loss of the samples, as the relative difference between the weight of the dried sample before and after the water immersion.

\subsubsection{Shrinkage and Weight Loss on Drying}

The susceptibility of mortars to shrinkage was determined by measuring the length of the samples immediately after forming and after complete drying. As before, three samples from each recipe were tested. The length of the samples was measured before moulding (mould length), and after 3, 6, 8, 10, 12,15 , and 19 days. During the length measurements, the samples were weighted to check their drying capacity and specify the weight loss on drying.

\subsubsection{Flexural Strength}

The flexural strength of the mortar samples (stored for 28 days in air-dry conditions) was determined following PN-EN 1015-11 standard [52] using the MTS 809 press (MTS System Corporation, Eden Prairie, MN, USA) on $40 \mathrm{~mm} \times 40 \mathrm{~mm} \times 160 \mathrm{~mm}$ trabeculars, under the movement of the press head of $0.2 \mathrm{~mm} / \mathrm{min}$. Four samples from each of the recipes were tested, but in the case of CM- 0 and CM-2, single samples were incorrectly destroyed, and the results were rejected.

\subsubsection{Compressive Strength}

The compressive strength of the of the mortar samples (stored for 28 days in air-dry conditions) was determined using the MTS 809 press on the broken half samples from flexural strength test following the PN-EN 1015-11 standard [52]. The displacement velocity of the press head was set at $8 \mathrm{~mm} / \mathrm{min}$. The test was conducted on six samples of each recipe.

\section{Results}

\subsection{Apparent Density, Specific Density, and Total Porosity}

Apparent density, specific density, and total porosity values are shown in Table 3. 
Table 3. Apparent density, specific density, and total porosity of the mortar (standard deviation in brackets).

\begin{tabular}{|c|c|c|c|}
\hline Mortar & $\begin{array}{c}\text { Apparent Density } \\
\left(\mathrm{kg} / \mathrm{m}^{3}\right)\end{array}$ & $\begin{array}{l}\text { Specific Density } \\
\left(\mathrm{kg} / \mathrm{m}^{3}\right)\end{array}$ & Total Porosity (\%) \\
\hline $\mathrm{CM}-0$ & $1802.0( \pm 19.3)$ & $2655.0( \pm 28.2)$ & $32.3( \pm 0.75)$ \\
\hline CM-1 & $1817.0( \pm 20.8)$ & $2644.0( \pm 9.2)$ & $31.3( \pm 0.76)$ \\
\hline CM-2 & $1853.0( \pm 19.0)$ & $2662.0( \pm 11.8)$ & $30.4( \pm 0.53)$ \\
\hline CM-3 & $1832.0( \pm 16.3)$ & $2656.0( \pm 15.2)$ & $31.0( \pm 0.44)$ \\
\hline
\end{tabular}

\subsection{Resistance to Water}

The results of the resistance to water test are shown in Figure 3. Error bars show standard deviation. Figure 4 shows the samples before they were placed in water, while Figure 5 shows the samples soaked in water for $1 \mathrm{~min}$.

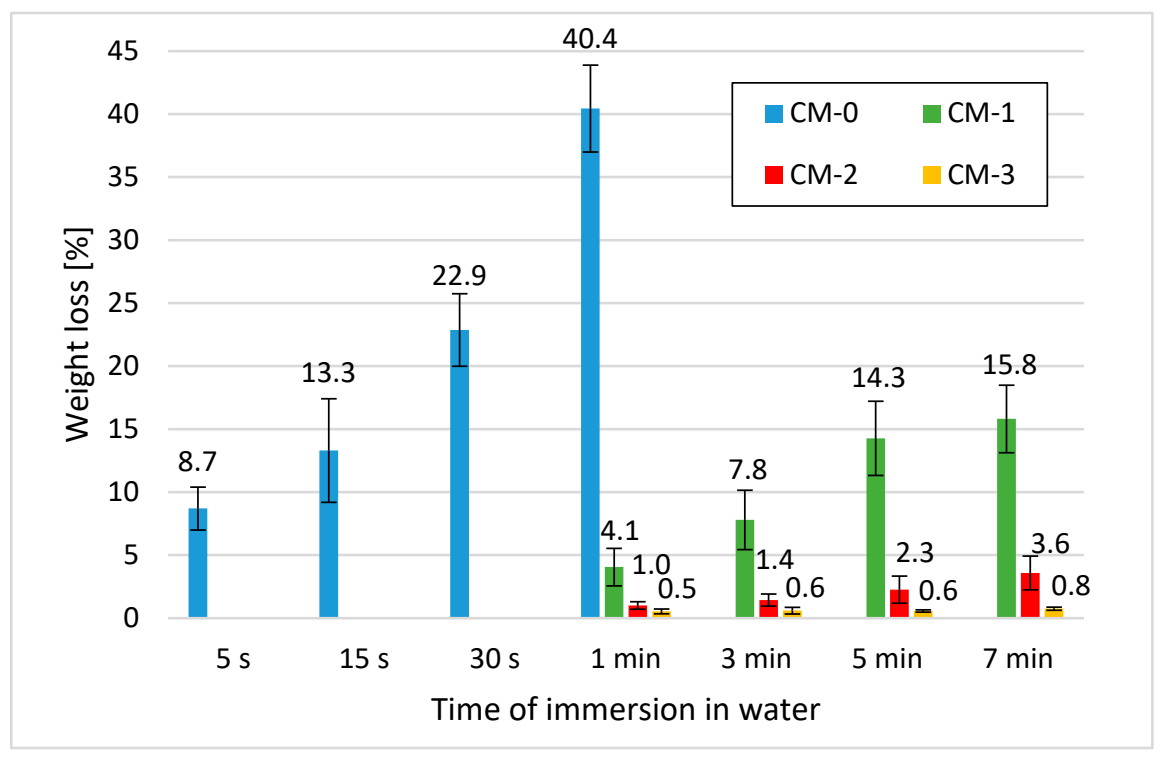

Figure 3. Weight loss of mortar samples after water immersion for a specified time.

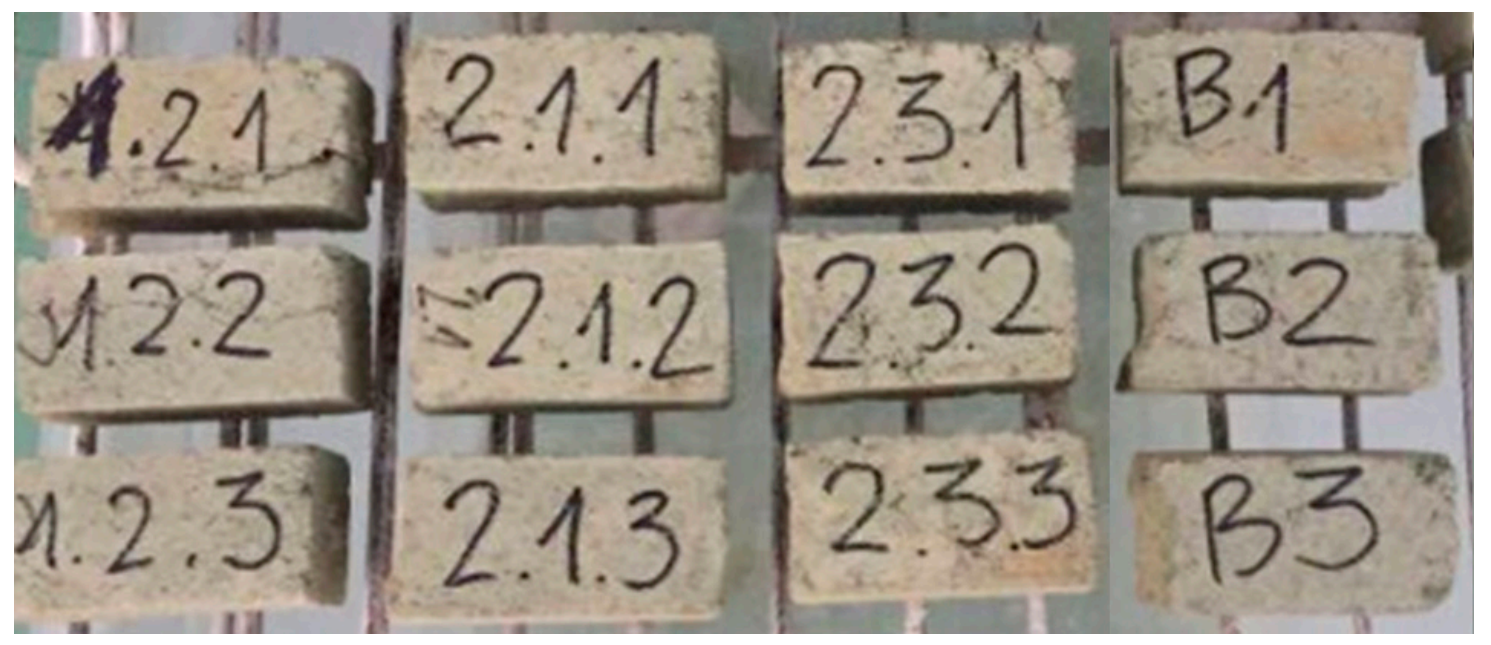

Figure 4. Glauconite clay mortar samples before the water immersion. From the left: CM-1, CM-2, CM-3, CM-0. 


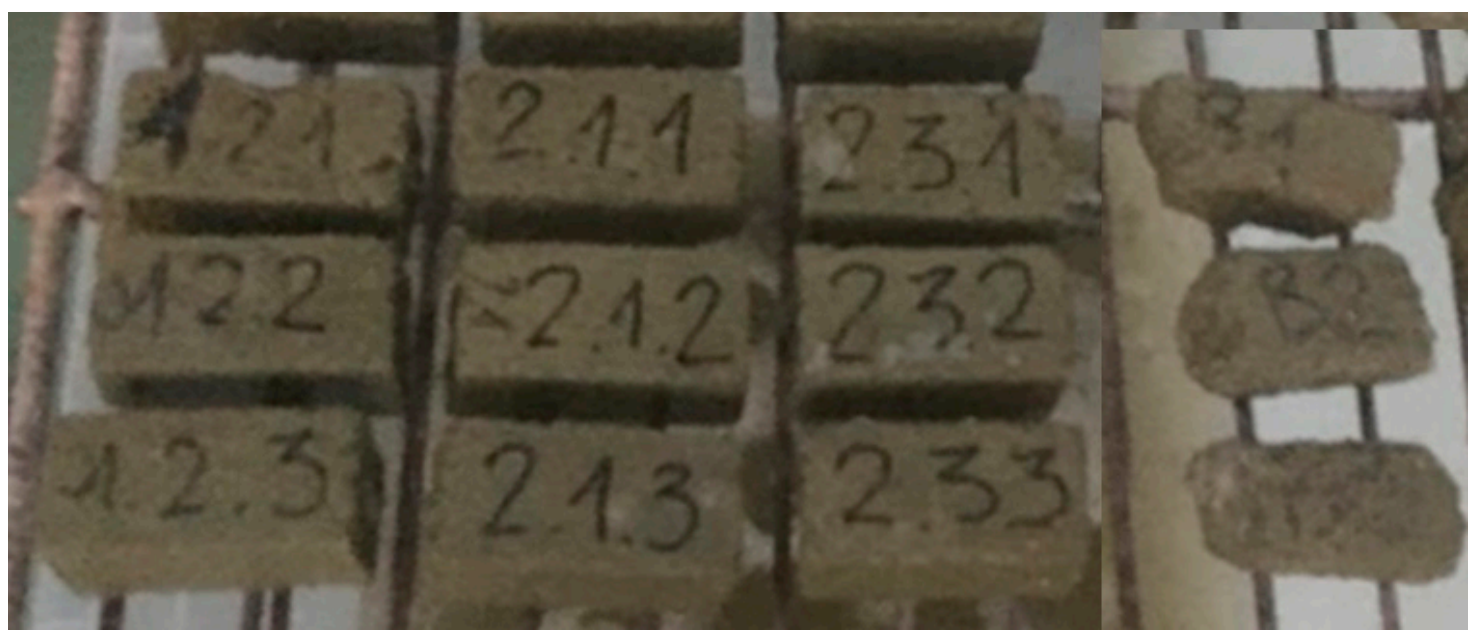

Figure 5. Glauconite clay mortar samples after $1 \mathrm{~min}$ of the water immersion. From the left: CM-1, CM-2, CM-3, CM-0.

\subsection{Shrinkage and the Weight Loss on Drying}

The average values of the length loss of the samples as a result of shrinkage and the standard deviation are shown in Table 4, and for better visualization of the results, the trends of the length loss over time are shown in Figure 6.

The average values of the mass loss of the samples over time and the standard deviation are shown in Table 5, while for better visualization of the results, the trends of the mass loss of the samples over time are shown in Figure 7.

Table 4. The average values of the length loss of the samples as a result of shrinkage and the standard deviation.

\begin{tabular}{|c|c|c|c|c|c|c|c|c|}
\hline \multirow{3}{*}{ Mortar } & \multicolumn{8}{|c|}{ Days of Measurement } \\
\hline & 0th & 3rd & 6th & 8th & 10th & 12th & 15th & 19th \\
\hline & \multicolumn{8}{|c|}{ Length Loss/ \pm SD (\%) } \\
\hline \multirow{2}{*}{ CM-0 } & 100.00 & 99.69 & 98.32 & 98.32 & 98.32 & 98.30 & 98.01 & 97.78 \\
\hline & \pm 0.00 & \pm 0.31 & \pm 0.36 & \pm 0.36 & \pm 0.36 & \pm 0.33 & \pm 0.18 & \pm 0.38 \\
\hline \multirow{2}{*}{ CM-1 } & 100.00 & 99.79 & 99.45 & 98.98 & 98.90 & 98.81 & 98.73 & 98.51 \\
\hline & \pm 0.00 & \pm 0.18 & \pm 0.48 & \pm 0.50 & \pm 0.43 & \pm 0.35 & \pm 0.31 & \pm 0.18 \\
\hline \multirow{2}{*}{$\mathrm{CM}-2$} & 100.00 & 99.79 & 99.49 & 99.40 & 99.46 & 99.23 & 99.10 & 99.10 \\
\hline & \pm 0.00 & \pm 0.10 & \pm 0.13 & \pm 0.08 & \pm 0.10 & \pm 0.24 & \pm 0.36 & \pm 0.34 \\
\hline \multirow{2}{*}{$\mathrm{CM}-3$} & 100.00 & 99.77 & 99.64 & 99.60 & 99.54 & 99.47 & 99.30 & 99.43 \\
\hline & \pm 0.00 & \pm 0.18 & \pm 0.18 & \pm 0.26 & \pm 0.20 & \pm 0.20 & \pm 0.44 & \pm 0.17 \\
\hline
\end{tabular}




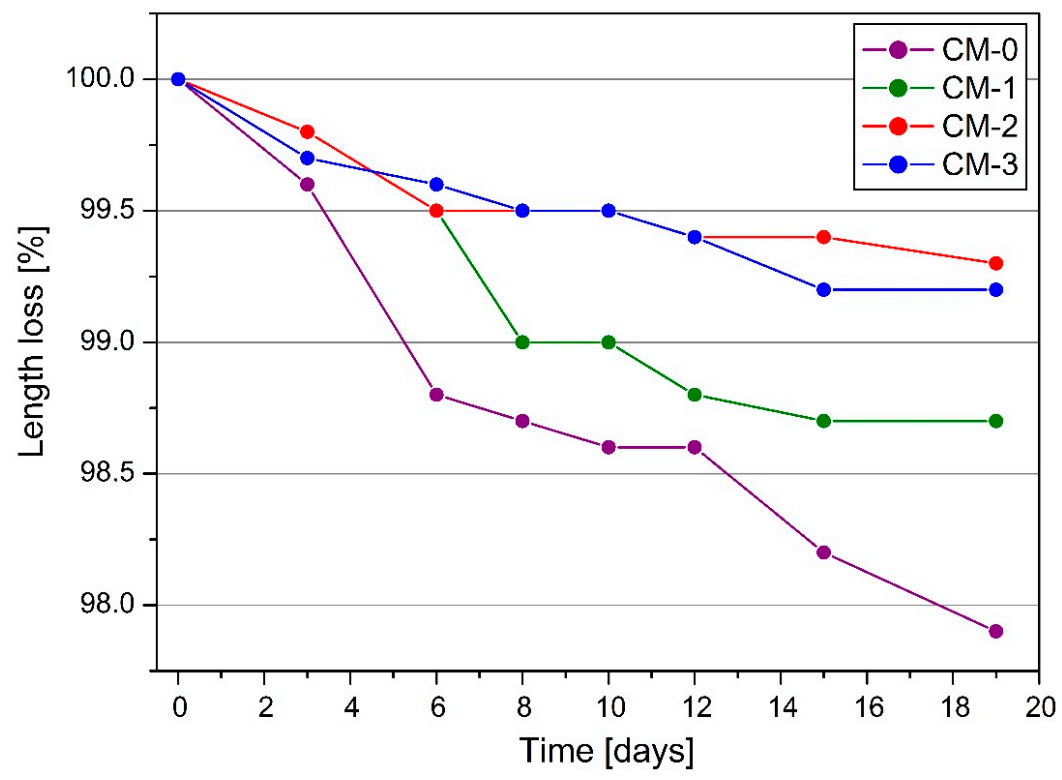

Figure 6. The average decrease in sample length on individual days.

Table 5. The average values of the mass loss of the samples over time and the standard deviation.

\begin{tabular}{ccccccccc}
\hline \multirow{2}{*}{ Mortar } & \multicolumn{7}{c}{ Days of Measurement } \\
\cline { 2 - 9 } & 0th & 3rd & 6th & 8th & 10th & 12th & 15th & 19th \\
\cline { 2 - 9 } & \multicolumn{7}{c}{ Mass Loss/ \pm SD (\%) } \\
\hline \multirow{2}{*}{ CM-0 } & 100.00 & 92.50 & 90.89 & 90.77 & 90.77 & 90.80 & 90.72 & 90.71 \\
& \pm 0.00 & \pm 0.34 & \pm 0.52 & \pm 0.51 & \pm 0.51 & \pm 0.57 & \pm 0.52 & \pm 0.52 \\
\hline \multirow{2}{*}{ CM-1 } & 100.00 & 92.94 & 91.42 & 91.13 & 90.46 & 91.35 & 91.21 & 91.22 \\
& \pm 0.00 & \pm 1.01 & \pm 0.94 & \pm 1.08 & \pm 0.98 & \pm 0.97 & \pm 1.00 & \pm 0.96 \\
\hline \multirow{2}{*}{ CM-2 } & 100.00 & 94.11 & 93.58 & 93.49 & 93.51 & 93.51 & 93.40 & 93.40 \\
& \pm 0.00 & \pm 0.35 & \pm 0.39 & \pm 0.46 & \pm 0.40 & \pm 0.39 & \pm 0.39 & \pm 0.40 \\
\hline \multirow{2}{*}{ CM-3 } & 100.00 & 95.38 & 94.43 & 94.31 & 94.34 & 94.28 & 94.27 & 94.20 \\
& \pm 0.00 & \pm 0.51 & \pm 0.56 & \pm 0.57 & \pm 0.44 & \pm 0.55 & \pm 0.64 & \pm 0.54 \\
\hline
\end{tabular}

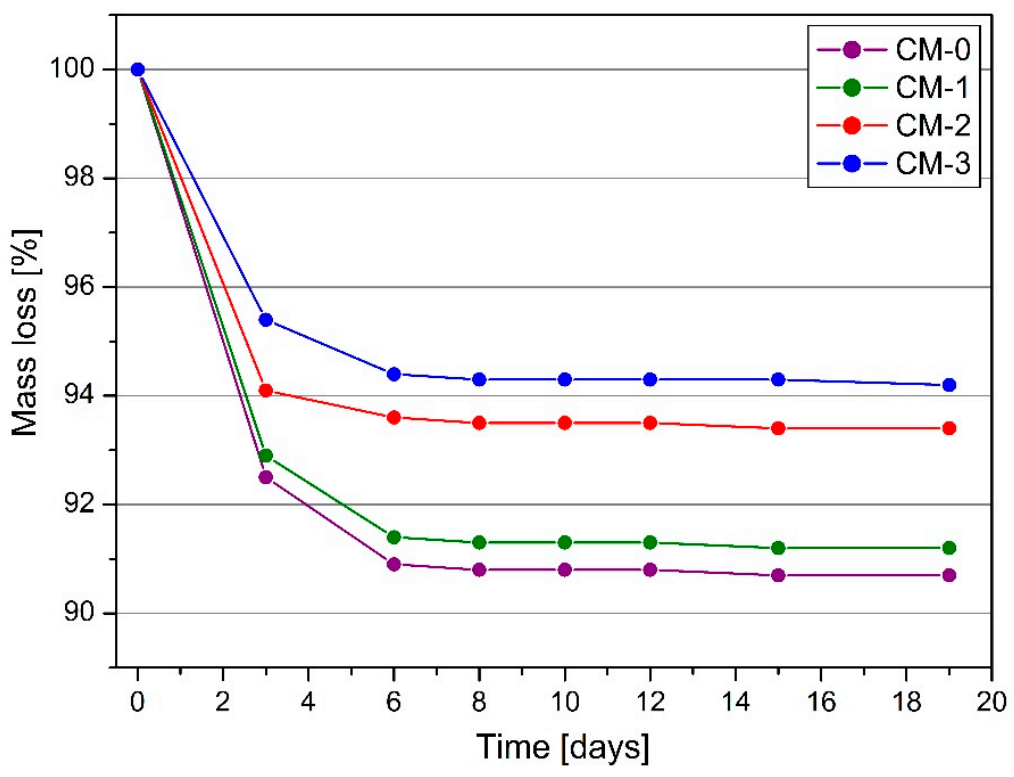

Figure 7. The average decrease in sample mass on individual days. 


\subsection{Flexural and Compressive Strength}

The results of the flexural and compressive strength tests are shown in Figures 8 and 9, respectively. Error bars depict standard deviation.

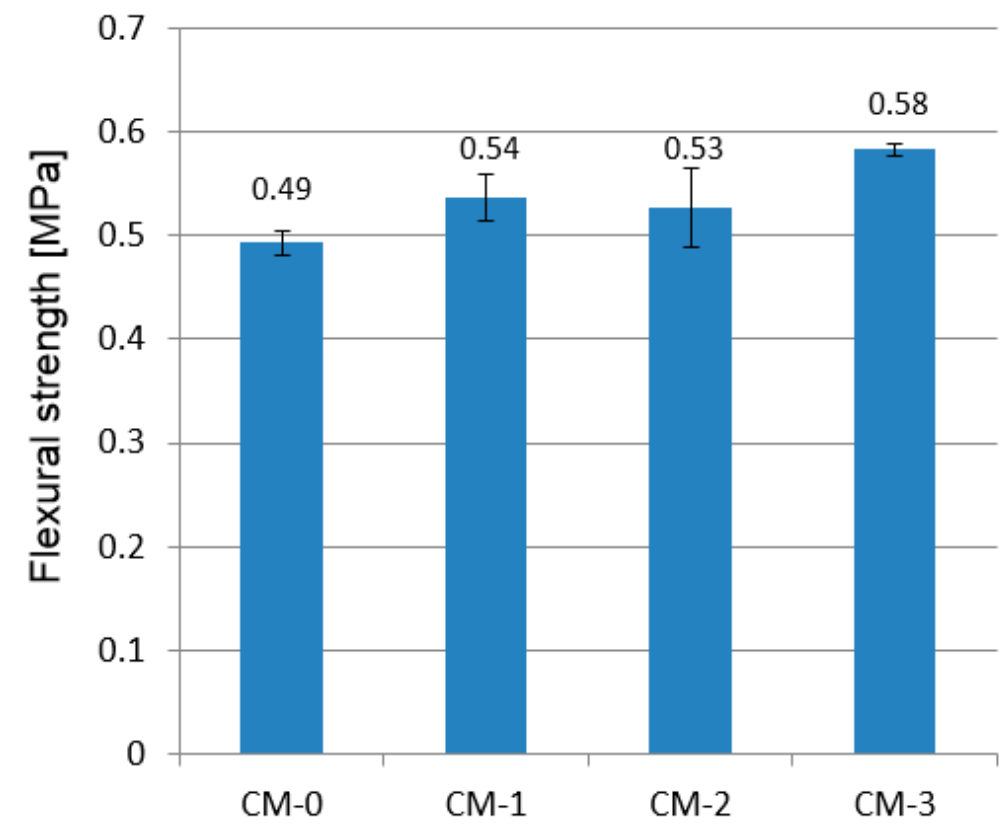

Figure 8. Flexural strength of tested mortars.

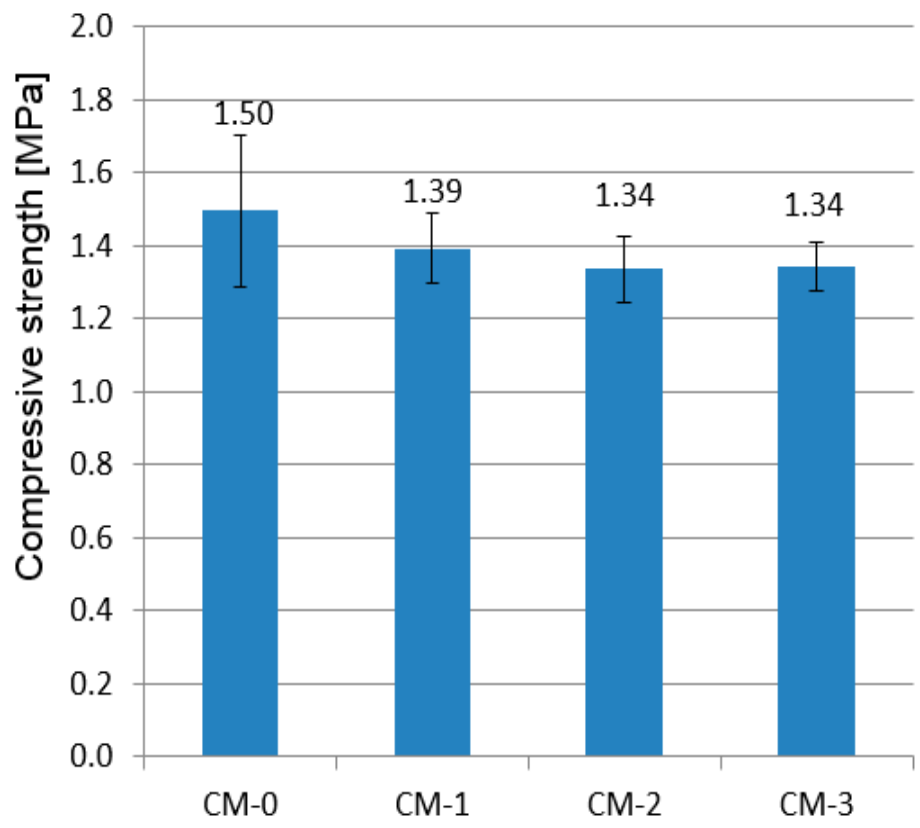

Figure 9. Compressive strength of tested mortars.

Besides the strength of the mortars, it is also important to know how they behave under increasing loads. Figure 10 shows the dependence of the bending force on displacement of the press head, while Figure 11 shows the compressive force and displacement of the press head during the mortar strength test. 

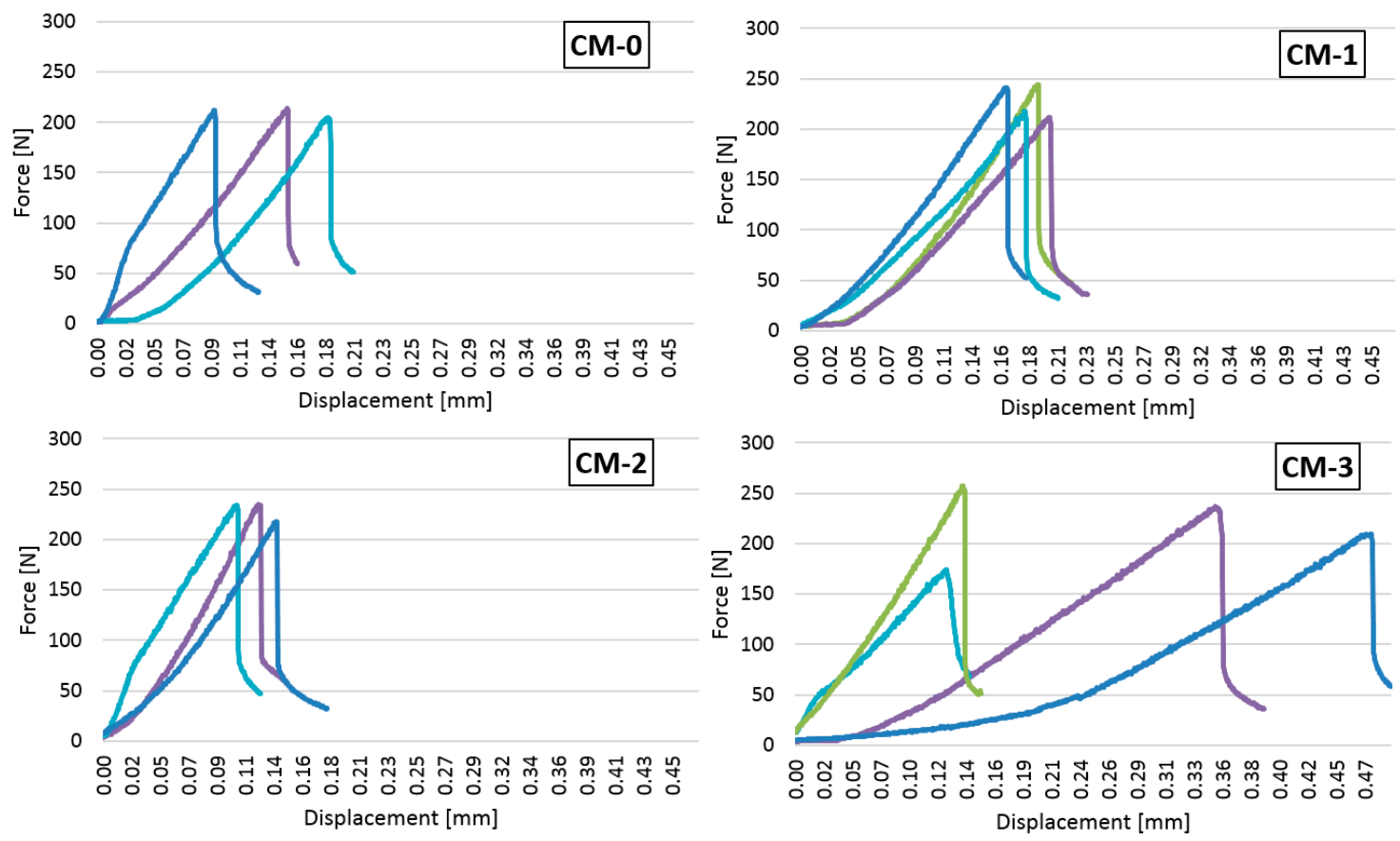

Figure 10. The dependence of the bending force on the displacement of the press head.
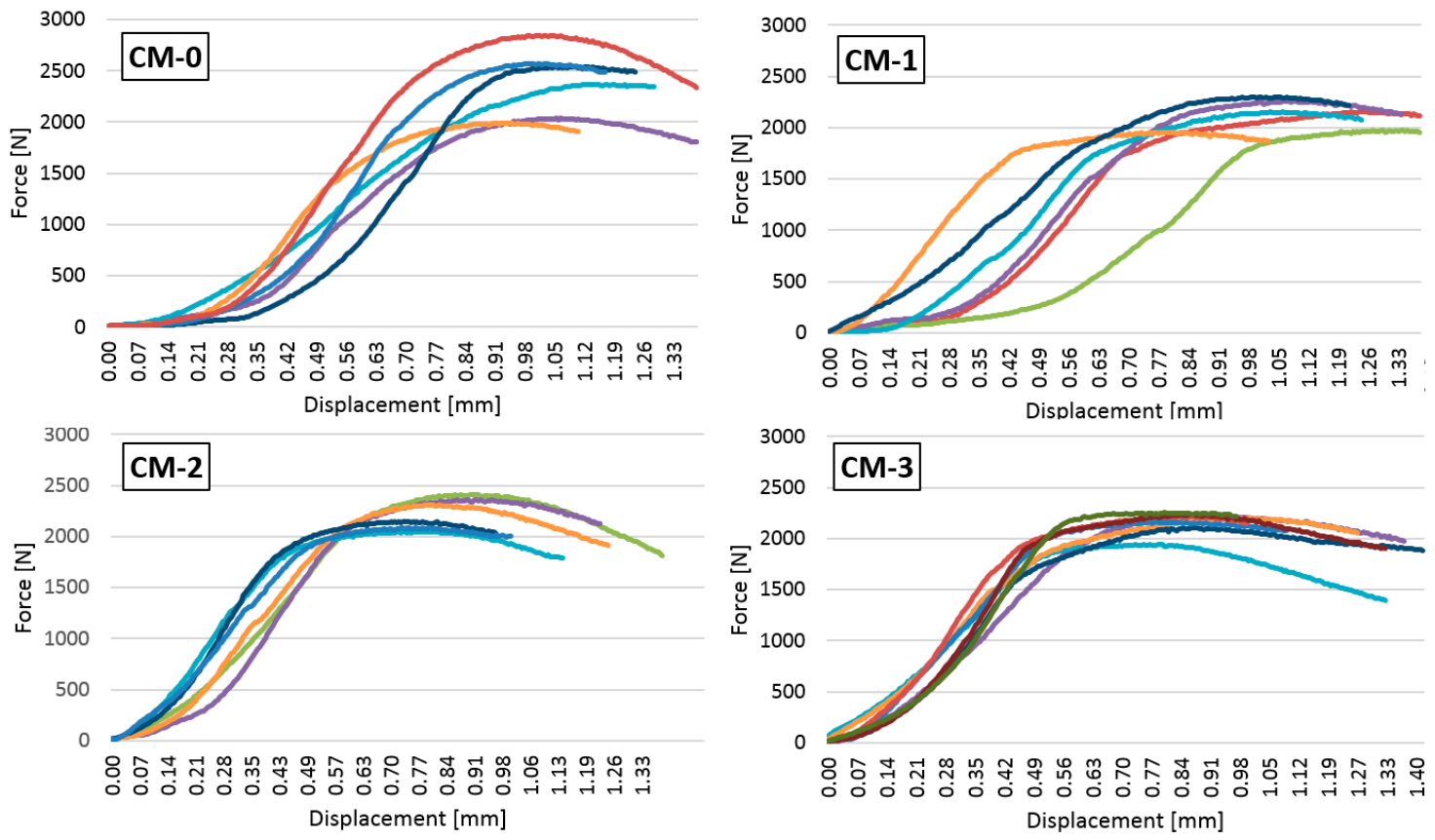

Figure 11. The dependence of the compressive force on the displacement of the press head.

\section{Discussion}

\subsection{Apparent Density, Specific Density, and Total Porosity}

The apparent density of the tested mortars ranged between 1802 and $1853 \mathrm{~kg} / \mathrm{m}^{3}$. The differences were small, and taking into account the standard deviation, it is difficult to determine the effect of the admixture of linseed oil varnish on the parameter. However, in all cases, the admixture led to an increase in bulk density. The admixture in the amount of $1 \%$ and $3 \%$ increased the mortar density by $0.2 \%$ and by $0.9 \%$, respectively, concerning the reference sample. The admixture in the amount 
of $2 \%$ caused the greatest increase in bulk density (by $2.8 \%$ ). The results may be influenced by the heterogeneity of sample compaction, so to draw conclusions more tests should be made.

Total porosity ranged between 30.4 and $32.3 \%$. The reference mortar had the highest porosity, which proves that the admixture of varnish affects the sealing of the material. The lowest porosity of the material was obtained with $2 \%$ linseed oil varnish content in the clay mass (porosity reduction by $5.9 \%$ ). Additions in the amount of $1 \%$ and $3 \%$ decreased the porosity by $3.1 \%$ and $4.0 \%$, respectively, compared to the reference sample. Other studies [23] showed that the admixture of linseed oil increased the porosity of lime mortars. Čechová, in turn, stated [25] that the admixture of linseed oil in the amount of $1 \%$ slightly reduced the porosity, while in the amount of $3 \%$ it increased the porosity of lime mortars. For a more precise assessment of the impact of porosity on the remaining properties of mortars, an analysis of the size and distribution of pores should be performed.

\subsection{Resistance to Water}

Clay is a material very susceptible to water, and as a result of its direct action, the bond strength is immediately broken. The samples without linseed varnish admixture achieved the most unfavourable result in the resistance to water test. After 1-min immersion, their weight decreased by almost half, as shown in Figure 5. For this reason, it was decided to reduce the time of their water bath to less than $1 \mathrm{~min}$. As the addition of linseed varnish increases, the mortar becomes more and more resistant to water. It is evidenced by the decrease in the loss of mortar mass. As the immersion time increases, the average weight loss increases for all recipes. The best results were achieved by samples with an admixture of linseed varnish in the amount of 3\% of the clay weight. After a 7-min bath, their weight decreased only by $0.8 \%$. The samples containing $2 \%$ of the admixture were ranked second with a good result. Their mass after a 7 -min immersion decreased by $3.6 \%$. The increase in water resistance is related to the fact that a substance with hydrophobic properties was introduced into the structure of the mortar, and during mixing, it created a water barrier on the surface of the clay and sand particles. Hydrophobization with linseed varnish led to a slight reduction in total porosity, which could also reduce the penetration of water into the mortar structure. The results prove that the structural hydrophobization of clay mortars with linseed varnish brought positive effects. However, increasing the amount of dopant should be considered. Minke and Krick in their work [53] report that the addition of linseed varnish in the amount of 4 and $6 \%$ of the clay plaster volume protects the plaster surface against rain erosion for more than 6 days, while clay plaster without additives erodes after $3 \mathrm{~s}$ of rain activity. The mechanisms and chemical reactions that occur when the lime binder is combined with linseed oil are described in Ref. [54]. Analogous analyses of the chemical reactions occurring in the combination of linseed oil with clay are needed. In other studies [22], after using 1.5\% casein and $4.5 \%$ hydrated lime to clay weight, it was possible to reduce the weight loss of clay mortar after $30 \mathrm{~min}$ of soaking in water to $1.9 \%$ compared to the non-soaked sample. On the other hand, the resistance of the material to the effect of water is often associated with a reduction in the vapour permeability $[26,53,55]$, which is why further research should relate to this issue.

\subsection{Shrinkage and Weight Loss on Drying}

Considering the samples ordered according to the growing amount of linseed oil admixture (from CM-0 to CM-3), the decrease in length after 19 days of measurements amounted to $2.2 \%, 1.5 \%$, $0.9 \%$, and $0.6 \%$, respectively, compared to the original size. As the addition of linseed varnish increased, the shrinkage decreased. Its value in the case of CM-3 mortar was reduced by $74.4 \%$ compared with the mortar without admixture. The influence of the higher admixture content on the parameter would also be worth investigating, as it is difficult to conclude on the effect of the insertion exceeding the $3 \%$ value.

All mortars showed the highest weight loss during the first 3 days after demoulding. Later, the results remained at the same level and slight declines were recorded. As the amount of linseed varnish increased, the percentage of weight loss during drying decreased. The varnish sealed the 
mortar, preventing the evaporation of free water. Samples without linseed varnish admixture showed $62.5 \%$ greater weight loss compared to CM-3. The weight loss values for each recipe were similar and had a small standard deviation. After 19 days, the mass of the samples was stabilized, and no weight loss was recorded in the following days. In another study [20], the drying capacity of lime mortars with an admixture of, among others, olive oil was examined. Weight loss progressed rapidly over the first 12 days, and the weight of the samples stabilized after 15 days.

\subsection{Flexural and Compressive Strength}

The flexural strength of the tested mortars ranged between 0.49 and $0.58 \mathrm{MPa}$ and the examined admixture improved the flexural strength. The additive of $1 \%$ and $2 \%$ increased the average strength of the mortars by $10.2 \%$ and $8.2 \%$, respectively, compared with the CM-0 formula. Samples with $3 \%$ varnish content achieved the highest strength $(0.58 \mathrm{MPa}-18.4 \%$ increase) and the smallest dispersion of results. The flexural strength of CM-2 samples was lower than CM-1, but the results were characterized by the highest standard deviation, so the test should be performed on a larger number of samples for comparison.

The compressive strength of the tested mortars ranged between 1.34 and $1.50 \mathrm{MPa}$. Each of the analysed contents of the admixture deteriorated the compressive strength of the mortar, the effect being the strongest for the highest amount of the varnish. However, it is worth noting that results obtained from the reference mortar tests showed the greatest discrepancy. After using the admixture, the results within each recipe were more uniform, so varnish improved the homogeneity of the material. The reason for the decrease in strength may be the fact that the aggregate is surrounded with linseed oil varnish, and thus the bond between the clay and sand is weakened. The second reason may be the fact that the samples were not dried at high temperature before testing but under natural, air-dry conditions. As a result, looking at Figure 7, the samples containing varnish admixture maintained a higher level of moisture which could also weaken the clay-sand bond. However, these phenomena should also cause a decrease in bending strength, but this increases with the amount of admixture. The admixture of varnish slightly decreased the total porosity, but it did not improve the strength parameters. A clear relationship between the total porosity and strength of other mortars modified by the linseed oil was not noticed in other studies as well $[23,24,56]$. Another study [57] investigated the effect of a $2 \%$ linseed oil admixture on the compressive strength of lime mortar. The admixture of oil caused a decrease in strength by approximately $32 \%$ compared to the reference mortar. The authors indicated that it may be caused by reduced carbonation, increased porosity, and weakening of the binder-aggregate contact zone due to the presence of oil. Čechová et al. [58], on the other hand, studied the effect of linseed oil admixture on the strength of lime mortars modified with pozzolana and cement. The oil admixture in the amount of $1 \%$ led to an increase in strength, while in the amount of $3 \%$ caused a drastic decrease in mortar strength. In turn, in the case of cement mortars, Justnes et al. [56] showed that the admixture of linseed oil in the amount of $0.5-1.5 \mathrm{wt} \%$ caused a significant decrease in mechanical strength.

The bending force-displacement plots (Figure 10) of the samples CM-1 and CM-2 are similar and do not show large discrepancies between the samples prepared according to each recipe. A larger divergence appeared for the CM-0 mortar-the destructive force caused a displacement of about $0.08 \mathrm{~mm}$ to $0.17 \mathrm{~mm}$. The greatest differences in the behaviour of the material under load were shown by samples based on the CM-3 formula. Although the values of the destructive force were similar, they produced a displacement ranging from $0.13 \mathrm{~mm}$ to $0.46 \mathrm{~mm}$. The CM-2 samples showed the greatest stiffness because the destruction occurred with the smallest deformation (axial displacement in the range of $0.09-0.14 \mathrm{~mm}$ ).

The dependence of the compressive force on the axial displacement of the compression head is shown in Figure 11. The smallest differences between the behaviour of individual samples within one recipe under increasing load were observed for the CM-2 and CM-3 recipes, where, as previously mentioned, the admixture of varnish improved the homogeneity of the mortars. The admixture of varnish in the amount of $2 \%$ and $3 \%$ improved the stiffness of the material, as the maximum 
compressive force (similar to the CM-1 samples) occurred with smaller deformation, in the range between 0.60 and $0.90 \mathrm{~mm}$.

\section{Conclusions}

This article presents research on the properties of glauconite clay mortars differing in the amount of linseed varnish admixture. A thorough analysis of the results made is possible to formulate the following conclusions:

1. The admixture of linseed oil varnish in the amounts used in the investigation had a positive effect on some of the tested properties; regardless of the quantity of the admixture, the modified mortars had better parameters concerning flexural strength, shrinkage reduction, and water resistance than the reference mortar, without admixture;

2. The admixture of varnish increased the flexural strength of the mortars, deteriorating their compressive strength; the improvement amounted to $18.4 \%$ in the case of the samples prepared according to the CM-3 recipe;

3. As the addition of linseed varnish increased, the mortar became more and more resistant to water; after a 7-min bath, the weight of samples with an admixture of linseed varnish in the amount of $3 \%$ of the clay weight (CM-3) decreased by only $0.8 \%$; the effect can be useful in developing recipes for external plasters;

4. The admixture of linseed varnish significantly reduced shrinkage; the best results were obtained by using the highest amount of admixture, and the shrinkage value of the CM-3 mortar was reduced by $74.4 \%$ compared with the shrinkage of the mortar without admixture;

5. The reference mortar without admixture was characterized by the highest total porosity, which proved that the addition of varnish sealed the mortar.

Currently, the authors are examining the influence of various admixtures, including linseed varnish, on the vapour permeability of clay mortars. It is an important property when the mortar is used as a plaster on walls made of organic materials, such as straw or hemp-lime composites.

Author Contributions: Conceptualization, P.B. and M.G.; methodology, P.B.; validation, P.B.; formal analysis, P.B. and M.G.; investigation, P.B.; resources, P.B.; data curation, P.B. and M.G.; writing-original draft preparation, P.B., M.G.; writing-review and editing, P.B. and M.G.; visualization, P.B. and M.G.; supervision, P.B. and M.G.; project administration, P.B.; funding acquisition, P.B. and M.G. All authors have read and agreed to the published version of the manuscript.

Funding: This research was financially supported by the Polish Ministry of Science and Higher Education under subvention for the statutory research program of scientific units.

Acknowledgments: The authors would like to thank Sylwia Sulowska for her contribution to the preparation and testing of the samples.

Conflicts of Interest: The authors declare no conflict of interest.

\section{References}

1. Minke, G. Building with Earth: Design and Technology of a Sustainable Architecture; Birkhäuser Architecture: Basel, Switzerland, 2012.

2. McGregor, F.; Heath, C.; Maskell, D.; Fabbri, A.; Morel, C. A review on the buffering capacity of earth building materials. Proc. Inst. Civ. Eng. Constr. Mater. Eng. 2016, 169, 241-251. [CrossRef]

3. Giada, G.; Caponetto, R.; Nocera, F. Hygrothermal properties of raw earth materials: A literature review. Sustainability 2019, 11, 5342. [CrossRef]

4. Allinson, D.; Hall, M. Hygrothermal analysis of a stabilised rammed earth test building in the UK. Energy Build. 2010, 42, 845-852. [CrossRef]

5. Karozou, A.; Stefanidou, N. Enhancing clay mortars' properties. In Proceedings of the 5th Historic Mortars Conference, Pamplona, Spain, 19-21 June 2019.

6. Curtis, R. Clay Mortars for Masonry Buildings. Historic Scotland, Edinburgh 2015. Available online: http://openarchive.icomos.org/1801/ (accessed on 30 November 2020). 
7. Agliata, R.; Marino, A.; Mollo, L.; Pariso, P. Historic building energy audit and retrofit simulation with hemp-lime plaster-A case study. Sustainability 2020, 12, 4620. [CrossRef]

8. Amin, N. Use of clay as a cement replacement in mortar and its chemical activation to reduce the cost and emission of greenhouse gases. Constr. Build. Mater. 2012, 34, 381-384. [CrossRef]

9. Galán-Marín, C.; Rivera-Gómez, C.; Petric, J. Clay-based composite stabilized with natural polymer and fibre. Constr. Build. Mater. 2010, 24, 1462-1468. [CrossRef]

10. Vejmelková, E.; Keppert, M.; Rovnaníková, P.; Keršnerc, Z.; Černy, R. Properties of lime composites containing a new type of pozzolana for the improvement of strength and durability. Compos. Part B 2012, 43, 3534-3540. [CrossRef]

11. Moropoulou, A.; Bakolas, A.; Moundoulas, P.; Aggelakopoulou, E.; Anagnostopoulou, S. Strength development and lime reaction in mortars for repairing historic masonries. Cem. Concr. Compos. 2005, 27, 289-294. [CrossRef]

12. Hippisley-Cox, C. Rediscovering Clay Mortars. Build. Eng. 2008, 1, $28-29$.

13. Kanema, J.M.; Eid, J.; Taibi, S. Shrinkage of earth concrete amended with recycled aggregates and superplasticizer: Impact on mechanical properties and cracks. Mater. Des. 2016, 109, 378-389. [CrossRef]

14. Alam, I.; Naseer, A.; Shah, A.A. Economical stabilization of clay for earth buildings construction in rainy and flood prone areas. Constr. Build. Mater. 2015, 77, 154-159. [CrossRef]

15. Artioli, G.; Secco, M.; Addis, A. The Vitruvian legacy: Mortars and binders before and after the Roman world. EMU Notes Mineral. 2019, 20, 151-202.

16. Snow, J.; Torney, C. Lime Mortars in Traditional Buildings. Short Guide 6; Historic Scotland: Edinburg, UK, 2014.

17. Nunes, C.; Slížková, Z. Freezing and thawing resistance of aerial lime mortar with metakaolin and a traditional water-repellent admixture. Constr. Build. Mater. 2016, 114, 896-905. [CrossRef]

18. Laborel-Préneron, A.; Aubert, J.E.; Magniont, C.; Tribout, C.; Bertron, A. Plant aggregates and fibers in earth construction materials: A review. Constr. Build. Mater. 2016, 111, 719-734. [CrossRef]

19. Aymerich, F.; Fenu, L.; Meloni, P. Effect of reinforcing wool fibres on fracture and energy absorption properties of an earthen material. Constr. Build. Mater. 2012, 27, 66-72. [CrossRef]

20. Ventolà, L.; Vendrell, M.; Giraldez, P.; Merino, L. Traditional organic additives improve lime mortars: New old materials for restoration and building natural stone fabrics. Constr. Build. Mater. 2011, 25, 3313-3318. [CrossRef]

21. Pintea, A.O.; Manea, D.L. Influence of natural organic polymers upon the mechanical properties of plaster mortars. Procedia Manuf. 2020, 46, 165-172. [CrossRef]

22. Brzyski, P.; Suchorab, Z. Physical properties of clay mortars based on insulating aggregates. In AIP Conference Proceedings 1988; AIP Publishing: College Park, MD, USA, 2018.

23. Nunes, C.; Slížková, Z. Hydrophobic lime based mortars with linseed oil: Characterization and durability assessment. Cem. Concr. Res. 2014, 61, 28-39. [CrossRef]

24. Nunes, C.; Mácová, P.; Frankeová, D.; Ševčík, R.; Viani, A. Influence of linseed oil on the microstructure and composition of lime and lime-metakaolin pastes after a long curing time. Constr. Build. Mater. 2018, 189, 787-796. [CrossRef]

25. Čechová, E. The Effect of Linseed Oil on the Properties of Lime-Based Restoration Mortars. Ph.D. Thesis, Università di Bologna, Bologna, Italy, 2009.

26. Pahlavan, P.; Manzi, S.; Rodriguez-Estrada, M.T.; Bignozzia, M.C. Valorization of spent cooking oils in hydrophobic waste-based lime mortars for restorative rendering applications. Constr. Build. Mater. 2017, 146, 199-209. [CrossRef]

27. Zunaithur Rahman, D.; Jeyamugesh, S.; Ilakkiya, N.; Vijayaraghavan, J. Mineral additive based mortar for the enhancement of water repellent properties. Eng. Tech. India 2016, 1, 157-165.

28. Oudhof, N.; Labat, M.; Magniont, C.; Nicot, P. Measurement of the hygrothermal properties of straw-clay mixtures. Acad. J. Civil. Eng. 2015, 33, 474-479.

29. Ashour, T.; Wieland, H.; Georg, H.; Bockisch, F.J.; Wu, W. The influence of natural reinforcement fibres on insulation values of earth plaster for straw bale buildings. Mater. Des. 2010, 31, 4676-4685. [CrossRef]

30. Ashour, T.; Georg, H.; Wu, W. An experimental investigation on equilibrium moisture content of earth plaster with natural reinforcement fibres for strawbale buildings. Appl. Therm. Eng. 2011, 31, 293-303. [CrossRef]

31. Aruan Efendy, M.G.; Pickering, K.L. Comparison of harakeke with hemp fibre as a potential reinforcement in composites. Compos. Part A Appl. Sci. Manuf. 2014, 67, 259-267. [CrossRef] 
32. Pacheco-Torgal, F.; Jalali, S. Cementitious building materials reinforced with vegetable fibres: A review. Constr. Build. Mater. 2011, 25, 575-581. [CrossRef]

33. Koutník, P.; Soukup, A.; Bezucha, P.; Kohout, J. Properties of mortars based on $\beta$-belite-metakaolinite-hydrated lime binder system. Constr. Build. Mater. 2020, 253, 119-123. [CrossRef]

34. Grilo, J.; Santos Silva, A.; Faria, P.; Gameiro, A.; Veiga, R.; Velos, A. Mechanical and mineralogical properties of natural hydraulic lime-metakaolin mortars in different curing conditions. Constr. Build. Mater. 2014, 51, 287-294. [CrossRef]

35. Nežerka, V.; Slížková, Z.; Tesárek, P.; Plachý, T.; Frankeová, D.; Petráňová, V. Comprehensive study on mechanical properties of lime-based pastes with additions of metakaolin and brick dust. Cem. Concr. Res. 2014, 64, 17-29. [CrossRef]

36. Aggelakopoulou, E.; Bakolas, A.; Moropoulou, A. Properties of lime-metakaolin mortars for the restoration of historic masonries. Appl. Clay Sci. 2011, 53, 15-19. [CrossRef]

37. Djobo, J.N.Y.; Elimbi, A.; Tchakouté, H.K.; Kumar, S. Mechanical properties and durability of volcanic ash based geopolymer mortars. Constr. Build. Mater. 2016, 124, 606-614. [CrossRef]

38. Celik, K.; Hay, R.; Hargis, C.W.; Moon, J. Effect of volcanic ash pozzolan or limestone replacement on hydration of Portland cement. Constr. Build. Mater. 2019, 197, 803-812. [CrossRef]

39. Vejmelková, E.; Keppert, M.; Keršner, Z.; Rovnaníková, P.; Černý, R. Mechanical, fracture-mechanical, hydric, thermal, and durability properties of lime-metakaolin plasters for renovation of historical buildings. Constr. Build. Mater. 2012, 31, 22-28. [CrossRef]

40. Yan, K.; Li, L.; Ge, D. Research on properties of bitumen mortar containing municipal solid waste incineration fly ash. Constr. Build. Mater. 2019, 218, 657-666. [CrossRef]

41. Del Curto, D.; Cinieri, V. Aerogel-based plasters and energy efficiency of historic buildings. literature review and guidelines for manufacturing specimens destined for thermal tests. Sustainability 2020, 12, 9457. [CrossRef]

42. Nunes, C.; Slížková, Z.; Křivánková, D. Lime-based mortars with linseed oil: Sodium chloride resistance assessment and characterization of the degraded material. Period. di Mineral. 2013, 82, 411-427. [CrossRef]

43. Vejmelková, E.; Koňáková, D.; Čáchová, M.; Keppert, M.; Černy, R. Effect of hydrophobization on the properties of lime-metakaolin plasters. Constr. Build. Mater. 2012, 37, 556-561. [CrossRef]

44. Izaguirre, A.; Lanas, J.; Álvarez, J.I. Effect of water-repellent admixtures on the behaviour of aerial lime-based mortars. Cem. Concr. Res. 2009, 39, 1095-1104. [CrossRef]

45. Falchi, L.; Müller, U.; Fontana, P.; Izzo, F.C.; Zendri, E. Influence and effectiveness of water-repellent admixtures on pozzolana-lime mortars for restoration application. Constr. Build. Mater. 2013, 49, 272-280. [CrossRef]

46. Vares, O.; Ruus, V.; Raamets, J.; Tungel, E. Determination of hygrothermal performance of clay-sand plaster: Influence of covering on sorption and water vapour permeability. Energy Procedia 2017, 132, 267-272. [CrossRef]

47. Brzyski, P.; Grudzińska, M.; Majerek, D. Analysis of the occurrence of thermal bridges in several variants of connections of the wall and the ground floor in construction technology with the use of a hemp-lime composite. Materials 2019, 12, 2392. [CrossRef]

48. Brzyski, P.; Łagód, G.; Suchorab, Z. Properties of a thermal-insulating wall material based on hemp shives and lime binder. In AIP Conference Proceedings 2170; AIP Publishing: College Park, MD, USA, 2019.

49. Stępniewski, W.; Pawłowska, M.; Gazda, L.; Widomski, M.; Franus, M.; Depta, M. Grunty Spoiste Lubelszczyzny Przydatne Do Budowy Mineralnych Barier Izolacyjnych i Innych ZASTOSOWAŃ inżynierskich; Lublin University of Technology Press: Lublin, Poland, 2015.

50. Polish Committee for Standardization. Methods of Test for Mortar for Masonry_Part 6: Determination of Bulk Density of Fresh Mortar; PN-EN 1015-6: 2000; Polish Committee for Standardization: Warsaw, Poland, 2000.

51. Polish Committee for Standardization. Natural Stone Test Methods-Determination of Real Density and Apparent Density, and of Total and Open Porosity; PN-EN 1936: 2010; Polish Committee for Standardization: Warsaw, Poland, 2010.

52. Polish Committee for Standardization. Methods of Test for Mortar for Masonry-Determination of Flexural and Compressive Strength of Hardened Mortar; PN-EN 1015-11:2020-04; Polish Committee for Standardization: Warsaw, Poland, 2020.

53. Minke, G.; Mahlke, F. Building with Straw, 1st ed.; Birkhäuser Architecture: Basel, Switzerland, 2005. 
54. Lazzari, M.; Chiantore, O. Drying and oxidative degradation of linseed oil. Polym. Degrad. Stab. 1999, 65, 303-313. [CrossRef]

55. Fromme, I.; Herz, U. Lehm- und Kalkputze; Ökobuch Verlag u. Versand: Staufen im Breisgau, Germany, 2012.

56. Justnes, H.; Ostnor, T.A.; Vila, B. Vegetable oils as water-repellents for mortars. In Proceedings of the International Conference of Asian Concrete Federation, Chiang Mai, Thailand, 28-29 October 2004; pp. 689-698.

57. Centauro, I.; Cantisani, E.; Grandin, C.; Salvini, A.; Vettori, S. The influence of natural organic materials on the properties of traditional lime-based mortars. Int. J. Archit. Herit. Conserv. Anal. Restor. 2017, 11, 670-684. [CrossRef]

58. Čechová, E.; Papayianni, J.; Stefanidou, M. Properties of Lime-Based Restoration Mortars Modified by the Addition of Linseed Oil. In Proceedings of the 2nd Historic Mortars Conference HMC2010 and RILEM TC 203-RHM Final Workshop, Prague, Czech Republic, 22-24 September 2010.

Publisher's Note: MDPI stays neutral with regard to jurisdictional claims in published maps and institutional affiliations.

(C) 2020 by the authors. Licensee MDPI, Basel, Switzerland. This article is an open access article distributed under the terms and conditions of the Creative Commons Attribution (CC BY) license (http://creativecommons.org/licenses/by/4.0/). 